\title{
UNIWERSYTET JAKO WSPÓLNE DOBRO I WSPÓLNY INTERES ${ }^{1}$
}

\author{
Pamięci Profesor Teresy Rabskiej \\ poświęcam
}

\section{WSTĘP}

Ostatnie kilka lat to czas ożywionej dyskusji nad kolejną restrukturyzacja nauki i szkolnictwa wyższego w Polsce, której efektem jest ustawa z 20 lipca 2018 r. - Prawo o szkolnictwie wyższym i nauce, zgodnie z modą ostatnich lat nazywana Konstytucją dla nauki 2.0. (cokolwiek to 2.0 oznacza). We wspomnianym akcie prawnym trudno jest jednak znaleźć bezpośrednie określenie tego, czym jest uniwersytet, a także inne wyższe polskie uczelnie. Nie ma też definicji nauki. O istocie czy charakterze tych placówek można jedynie wnioskować z ustawowo wskazywanych struktur, funkcji i zasad funkcjonowania. W istocie rzeczy chyba trudno jest, w sposób prosty, a zarazem treściwy, określić, czym jest uniwersytet, kiedy inną rolę odgrywa w społeczeństwie, inna w nauce, czym innym jest dla pracowników, a czym innym dla studentów. Inne jest ponadto miejsce uniwersytetu i jego rola w życiu społeczno-gospodarczym danej miejscowości, regionu oraz kraju, a także znaczenie w nauce nie tylko polskiej.

W niniejszym opracowaniu, przy założeniu podejścia systemowego, przedstawione będzie pojmowanie uniwersytetu jako dobra wspólnego i wspólnego interesu pracowników (w mniejszym stopniu studentów). Taki punkt widzenia wynika z szczególnego znaczenia, jakie w funkcjonowaniu uniwersytetu, jego rozwoju i społecznej roli, odgrywają właśnie pracownicy. To oni w gruncie rzeczy, wraz z potrzebną (i dostępna) do pracy naukowej i dydaktycznej infrastruktura, tworzą pewną całość, którą nazwać można uniwersytetem. Może właśnie z takiego punktu widzenia wynika częste określanie uniwersytetu jako wspólnoty nauczających i uczących się, choć w takim ujęciu ginie gdzieś strona naukowa działania tego rodzaju placówek ${ }^{2}$. Być może zbyt opty-

\footnotetext{
${ }^{1}$ Rozważania zawarte w niniejszym tekście odnieść można także do innych kategorii wyższych uczelni, wydziałów, instytutów, katedr, zakładów i podobnych jednostek organizacyjnych.

2 Autor niniejszego tekstu działalność naukową uznaje za podstawową dla tego rodzaju szkoły wyższej, jaka jest uniwersytet. Działalność edukacyjną traktuje zaś jako pochodną działalności naukowej, jednakże odnoszoną do procesu kształcenia elity intelektualnej.
} 
mistycznie brzmi uznanie za dobro miejsca pracy, jakim dla pracowników jest uniwersytet, a realizacji przypisanych zadań - za realizację wspólnego interesu. Wydaje się jednak, że takie potraktowanie uniwersytetu może się jednak przyczynić do lepszego, a zarazem bardziej efektywnego funkcjonowania tej placówki, co w czasach istnienia wielu różnego rodzaju problemów, podziałów, interesów czy konfliktów, jakie niesie ze sobą rewolucja (którą jest niewątpliwie wprowadzanie w życie zapisów Konstytucji dla nauki 2.0), nie jest bez znaczenia. Co więcej, raczej zyskuje lub będzie zyskiwać na znaczeniu, kiedy w szkolnictwie wyższym, zgodnie z treścią wspomnianej ustawy, wprowadzane będą głębokie zmiany, bez wattpienia rewolucyjnego, w stosunku do powojennej tradycji i ukształtowanego charakteru.

Celem niniejszego artykułu jest odniesienie idei czy koncepcji dobra wspólnego, a także wspólnego interesu do organizacji, struktury i funkcjonowania uniwersytetu. Uniwersytetu traktowanego jako charakterystyczny system społeczny, funkcjonujący w otoczeniu, jakim jest życie społeczno-gospodarcze kraju. System z natury rzeczy teleologiczny, jego celem jest bowiem z jednej strony tworzenie wiedzy, a z drugiej - kształcenie wysokiej jakości specjalistów. Oczywiście jest to zapewne jedno z wielu możliwych spojrzeń na uniwersytet, i to spojrzenie wybitnie subiektywne. Nawiazuje jednak do tego, w jaki sposób patrzyła na uniwersytet w trudnym okresie jego funkcjonowania, na początku lat osiemdziesiątych XX w., Profesor Teresa Rabska, prorektor Uniwersytetu im. Adama Mickiewicza w Poznaniu, a zarazem wieloletni redaktor naczelny „Ruchu Prawniczego, Ekonomicznego i Socjologicznego”, której pamięci dedykowany jest niniejszy tekst.

\section{NIECO REFLEKSJI W NAWIĄZANIU DO NIEODLEGŁEJ PRZESZLOŚCI}

Próby reformy polskiego systemu nauki i szkolnictwa wyższego podejmowane były w ostatnich latach kilkakrotnie. Sam dość dobrze pamiętam działania w tym zakresie, jakie podejmował rząd kierowany przez Jana Olszewskiego. Wtedy to działający z upoważnienia premiera prof. Antoni Kukliński, ówczesny wiceprzewodniczący Komitetu Badań Naukowych (przedtem także podsekretarz Stanu w Ministerstwie Spraw Zagranicznych), utworzył zespoły mające przygotować raport o stanie nauki polskiej i zaproponować kierunki zmian. Jednemu z zespołów przewodniczył mój szef prof. Zbyszko Chojnicki, który zaproponował mi (wtedy docentowi, oczekującemu na tytuł profesorski - otrzymałem go za kilka miesięcy) uczestnictwo w tym zespole, przydzielając zadanie dokonania ekspertyzy dotyczacej ekonomicznych uwarunkowań funkcjonowania i rozwoju nauki i szkolnictwa wyższego. Było to zadanie trudne, którego się jednak podjąłem, mając w pamięci raport o sytuacji materialnej pracowników naukowych Uniwersytetu im. Adama Mickiewicza w Poznaniu (UAM), który pod moim kierunkiem został przygotowany kilka lat wcześniej w ramach powołanej do tego celu Komisji Senatu UAM. Niestety, eksperty- 
za moja nie doczekała się opublikowania, prawdopodobnie przede wszystkim z uwagi na zbyt daleko idące propozycje, wynikające z przyjętej - nie do zaakceptowania politycznie hipotezy (choć zapewne i ze względów na inne sugestie), że na naukę i szkolnictwo wyższe w Polsce nie będzie nigdy wystarczających środków finansowych. Pewne wnioski z tamtej ekspertyzy oraz inne, wyciągnięte z kolejnych 25 lat funkcjonowania tej sfery życia społecznego, zawarłem w uwagach, które przed ponad dwoma laty skierowałem, droga pocztowa, do Gabinetu Ministra Nauki i Szkolnictwa Wyższego, wicepremiera dr. Jarosława Gowina. Zabierajac głos w sprawie reformy systemu nauki i szkolnictwa wyższego, prawdopodobnie spełniłem jedynie jakiśs swój obywatelski obowiązek, nie zakładam bowiem, aby ktokolwiek w nawale prac i zgłaszanych propozycji ten niemal 20-stronicowy tekst przeczytał i starał się wyciagnąć z niego jakieś wnioski. Nie otrzymałem także, zgodnie z wieloletnią tradycją tego resortu, potwierdzenia otrzymania moich uwag. Może zatem tylko w tym miejscu przytoczę - i to w dużym skrócie - moje najważniejsze uwagi. Te pierwsze zostały sformułowane już w roku 1992, we wspomnianym raporcie.

Będąc zwolennikiem ogólnej teorii systemów, sformułowanej przez Ludwiga von Bertalanffy'ego, a tym samym systemowego traktowania rzeczywistości, naukę i szkolnictwo wyższe traktuję także jako system ${ }^{3}$. Oznaczało to przyjęcie w raporcie takiego podstawowego założenia, że przystosowanie nauki i szkolnictwa wyższego do funkcjonowania w nowych warunkach ustrojowych wymaga zmian systemowych. Niestety, sformułowałem pesymistyczną hipotezę główna, a mianowicie taka, że na naukę i szkolnictwo wyższe w Polsce nie będzie nigdy wystarczającej ilości środków, co oznacza konieczność efektywnego wykorzystania tego, co jest dostępne. Następne lata dowiodły trafności tej hipotezy.

Konsekwencją przyjęcia tej hipotezy (choć w mniejszym stopniu także i innych założeń wstępnych) były sformułowane postulaty czy propozycje. Pierwszym był postulat utworzenia dużych uniwersytetów, łączących wyższe uczelnie w danej miejscowości, oraz utworzenie wyższych, państwowych szkół zawodowych ${ }^{4}$. Uniwersytety kształcić miałyby elitę intelektualna, a wyższe szkoły zawodowe - potrzebnych krajowi fachowców na poziomie licencjackim i inżynierskim. Do uniwersytetów miałyby zostać włączone instytuty panowskie i resortowe, z wyjątkiem tych, które prezentowały najwyższy poziom nauki. Z tych należałoby utworzyć państwowe instytuty naukowe. Powinny to być także jednostki, które mogłyby podjąć się rozwiązywania najważniejszych dla państwa i społeczeństwa problemów (problemy zdrowia, bezpieczeństwa, rozwoju ekonomicznego itp.). Polska Akademia Nauk miałaby przekształcić się w korporację najwybitniejszych polskich uczonych, wyznaczająca kierunki rozwoju nauki i oceniającą ten rozwój (coś na kształt obecnego prezydium PAN-u i „odchudzonych” panowskich komitetów dyscyplin naukowych). Podstawowym zadaniem uniwersytetów miało być przede wszystkim prowadzenie badań naukowych, których wyniki miałyby być następnie wykorzystywane,

\footnotetext{
3 Von Bertalanffy (1968); (1950): 134-165.

${ }^{4}$ Nie było wtedy takiej kategorii szkół ani też prywatnych szkół wyższych.
} 
także w procesie kształcenia wysoko kwalifikowanych kadr. Rozwiązanie takie pozwoliłoby z jednej strony skoncentrować potencjał badawczy i polskie uniwersytety uczynić bardziej znaczącymi w Europie, a z drugiej - dokonać redukcji zatrudnienia $\mathrm{w}$ sferze administracji (administracja jednej uczelni musi być mniejsza niż kilku tworzących aktualnie tę całość placówek), a także częściowo personelu naukowego i naukowego-technicznego (w włączonych do uniwersytetu szkołach wyższych i instytutach funkcjonowało wiele podobnych jednostek: zakładów, katedr, instytutów, np.: matematyki, fizyki, ekonomii politycznej, filozofii, nauk społecznych, studiów języków obcych, wychowania fizycznego itp.). Obniżkę poziomu zatrudnienia, a tym samym oszczędność środków, dałaby także likwidacja bloku przedmiotów ideologiczno-politycznych, które powinny zostać zastapione, stosownie do charakteru uczelni, przez filozofię, logikę, metodologię, a także ekonomię (choć już nie tylko i niekoniecznie polityczna, a raczej makro-i mikroekonomię). Efektem takiego rozwiązania byłaby obniżka ogólnych kosztów funkcjonowania uniwersytetów, a uzyskane tą droga środki mogłyby zostać przeznaczone przede wszystkim na badania naukowe oraz na podniesienie standardu nauczania.

Duże uniwersytety powinny prowadzić badania naukowe globalnego i europejskiego znaczenia oraz, co już napisano, kształcić elitę intelektualną społeczeństwa. Logiczną konsekwencją kształcenia elity intelektualnej, a tym samym najwyższej rangi fachowców, miałoby być zmniejszenie liczby studentów, także zmniejszające koszty funkcjonowania jednostek, a zatem przynoszące określone oszczędności. Poziom intelektualny, prezentowana wiedza oraz poważne podejście do studiów potencjalnych studentów, także potrzeby kraju, a nie dążenie do wysokiego poziomu wskaźnika scholaryzacji, powinny regulować liczbę przyjmowanych studentów ${ }^{5}$.

Przyjąłem ponadto, a co zostało już także napisane, że kształceniem potrzebnej krajowi, podstawowej kadry fachowej na poziomie ponadlicealnym powinny zająć się utworzone państwowe wyższe szkoły zawodowe (np. na wzór niemieckich). Tego typu placówki zostały zresztą utworzone kilka lat później. Powstały także liczne, prywatne szkoły wyższe. Tam też mieli znaleźć zatrudnienie pracownicy, którzy utraciliby swoje dotychczasowe miejsca pracy w szkołach wyższych, placówkach PAN-u włączonych w skład uniwersytetów i instytutach resortowych. Inne „zwolnione” osoby miały znaleźć miejsca pracy w szkolnictwie średnim oraz prywatyzującej się gospodarce (np. w usługach).

Struktura organizacyjna uniwersytetów miałaby nawiązywać do tego, co jest zakorzenione w tradycji uniwersyteckiej i co dyktuje rozwój cywilizacyjno-

5 Systematyczne powiększanie liczby studentów bez względu na ich możliwości intelektualne przyczyniło się do poważnego obniżenia ogólnego poziomu kształcenia. Przyczyną rozwoju takiej praktyki było uzależnienie sytuacji materialnej uniwersytetów i innych szkół wyższych od liczby studentów. W ten sposób z modelu „uniwersytetu” szkoły wyższe zaczęły funkcjonować w modelu „supermarketu”, obniżając systematycznie kryteria przyjęć (przeceny) oraz ogłaszając kolejne terminy naborów, w tym także dla osób poprawiających maturę (promocje, wyprzedaże). Uniwersytety zamiast kształcić i dostarczać wiedzy, stały się biurami wydawania dyplomów. Oczywiście nie oznacza to, że absolwentami uniwersytetów nie były osoby wybitnie uzdolnione i bardzo dobrze wykształcone. Średni poziom kształcenie ulegał jednak systematycznej obniżce. Osoby stawiające duże wymagania traktowane zaś były jako szkodzący sytuacji materialnej uczelni. 
-kulturowy. W ramach takiej struktury powinien być prowadzony proces kształcenia, z jego dostosowaniem do potrzeb państwa, społeczeństwa i gospodarki. Pierwszym krokiem na drodze do kształcenia elity intelektualnej społeczeństwa powinna być rekrutacja kandydatów na studia, oparta na procedurze egzaminacyjnej oraz zwiąane z rekrutacją ograniczenie liczby przyjmowanych studentów, co oznaczać powinno, jakościowa, a nie ilościową orientację kształcenia (przekleństwo wskaźników scholaryzacji).

Kadrę naukowo-dydaktyczną uniwersytetów miałyby stanowić osoby uzdolnione, dla których praca naukowo-badawcza i dydaktyczna jest i powołaniem (to samo powinno dotyczyć lekarzy, nauczycieli i osoby duchowne), i pasja. Osoby takie nie moga jednak funkcjonować w sytuacji materialnej, w której troska o byt własny i rodziny odrywa je od pracy naukowej i dydaktycznej, zarówno przez poszukiwanie miejsc dodatkowego zarobku w innych miejscach pracy, jak i przyjmowanie dodatkowych zajęć dydaktycznych w miejscu podstawowym. Jest sprawą oczywista, że tego rodzaju działania zawsze się odbywały i odbywać się będą nie tylko kosztem prowadzonych badań, ale także czasu potrzebnego na poszerzanie zakresu posiadanej wiedzy oraz wypoczynku, niezbędnego w warunkach prowadzenia intensywnej pracy umysłowej. Otrzymywane wynagrodzenie powinno uwzględniać: funkcje społeczne wykonywanej pracy, poziom wykształcenia, zajmowane stanowisko, a także takie potrzeby, jak: książki i czasopisma, sprzęt komputerowy i jego oprogramowanie, uczestnictwo w życiu naukowym, uczestnictwo w kulturze, specyficzne potrzeby egzystencjalne (np. przyzwoity ubiór, miejsce do pracy w domu) itp. Otrzymywane wynagrodzenie powinno także uwzględniać w gruncie rzeczy nienormowany czas pracy pracowników naukowych. Warto także pamiętać, że w przypadku osób traktujących swoja pracę jako powołanie oraz pasję organizacja własnego życia koncentruje się wtedy przede wszystkim wokół pracy oraz zainteresowań naukowych, często kosztem rodziny. Przyjąłem ponadto (w warunkach przełomu lat 1991/1992), że podstawowym źródłem finansowania nauki i szkolnictwa wyższego będzie nadal budżet państwa, w tym także przez finansowanie projektów badawczych (znane mi wtedy były tzw. programy węzłowe, międzyresortowe i późniejsze projekty finansowane przez utworzony Komitet Badań Naukowych, czyli tzw. granty). Mimo pesymistycznej oceny sytuacji materialnej nauki i szkolnictwa wyższego oraz słabej nadziei na poprawę sytuacji w tym względzie, postulowałem znaczne podniesienie udziału tego sektora życia społecznego kraju w produkcie krajowym brutto (PKB), przy pełnej świadomości tego, że w nawiązaniu do PKB państw Europy Zachodniej, sa to zupełnie innej wielkości sumy pieniędzy. Produkt krajowy brutto jest jakaśs, i to powszechnie stosowana, miara wydatków budżetowych na konkretną dziedzinę życia społecznego, jednakże ryzykowne jest $\mathrm{w}$ tym względzie stosowanie analiz porównawczych w odniesieniu do innych krajów 6 .

${ }^{6}$ Przy tej okazji warto nadmienić, że udział środków na naukę i szkolnictwo wyższe w PKB nie jest dobrym wskaźnikiem poziomu finansowania tej sfery życia społecznego. Znacznie lepiej sytuację materialną nauki i szkół wyższych odwzorowuje kwota budżetu przeznaczonego na placówki naukowe i naukowo-dydaktyczne, jaka przypada na 1 mieszkańca kraju, 1 osobę pracująca w sektorze nauki i szkolnictwa wyższego, a przy funkcjonującym w Polsce ilościowym modelu edu- 
Koncentrując się na sprawach ekonomiczno-finansowych, nie zajmowałem się w wykonanej ekspertyzie tego rodzaju, w sumie bardzo ważnymi, sprawami, jak: polityka naukowa państwa, organizacja badań, funkcjonowanie „szkół naukowych", drogi awansu, ocena działalności naukowej, oceny parametryczne (nie było wtedy punktowania i indeksowania dorobku, listy filadelfijskiej itp.), oceny działalności dydaktycznej (akredytacje, Krajowe Ramy Kwalifikacji itp.). Takie innowacje, jak te wymienione jako ostatnie, w systemie nauki i szkolnictwa wyższego nie były jeszcze obecne. Dziśs są, choć pochłaniają sporo czasu i środków tak bardzo potrzebnych do prowadzenia badań naukowych. Nie odnosiłem się także do wysokości wynagrodzeń, jakie powinny wchodzić w rachubę w początkowym okresie polskiej transformacji ustrojowej. W dalszej części elaboratu przedstawiłem niektóre kierunki reformowania systemu, których syntetyczną i subiektywną ocenę zawarłem w podsumowaniu ${ }^{7}$. Wszystko to miało być rodzajem diagnozy sytuacji z początku lat dziewięćdziesiątych XX w., której wyniki być może należałoby ponownie rozważyć po niemal 25 latach od czasu ich sformułowania, przystępując do rewolucyjnych zmian, jakie aktualnie znajdują się w fazie wprowadzania w życie.

Prezentując swoje, powyżej zapisane, choć sformułowane w innych warunkach uwagi, zakładałem, że wielu przedstawicieli nauki i szkolnictwa wyższego przedstawi swoje na temat kierunków rekonstrukturyzacji systemu nauki i szkolnictwa wyższego w Polsce. Aktualnie nie wiem i wiedzieć tego nie będę, czy i w jakim stopniu ktokolwiek z decydentów w sprawie nauki i szkolnictwa wyższego brał pod uwagę przedstawiane przez różne osoby propozycje. Bez względu na trafność, słuszność, zasadność, wagę, racjonalność czy poziom demagogii sformułowanych w 1992 r. uwag - źle się jednak stało, że w trudnym dla społeczeństwa okresie pierwszych lat transformacji nie dokonano systemowej rekonstrukcji modelu organizacji, struktury i funkcjonowania nauki i szkolnictwa wyższego. Zamiast efektywnych systemowych rozwiązań co jakiś czas wprowadzano doraźnie takie, które wbrew zapowiedziom ani nie rekonstruowały systemu organizacyjnego i funkcjonowania nauki i szkolnictwa wyższego, ani nie zwiększyły świadczeń finansowych na rozwój nauki, ani nie podniosły rangi i znaczenia nauki polskiej, ani też nie poprawiły poziomu kształcenia. Innymi słowy, wprowadzane zmiany nie uczyniły z tej sfery życia społecznego, jaka jest nauka i szkolnictwo wyższe, ważnego czynnika rozwoju społeczno-ekonomicznego (gospodarka oparta na wiedzy) ${ }^{8}$. Nie doprowadziły także do tworzenia tzw. klasy kreatywnej, do wzrostu znaczenia nauki w wymiarze globalnym i europejskim oraz do podniesienia poziomu jej konkurencyjności, a wręcz przeciwnie ${ }^{9}$.

kacji na poziomie wyższym - wymieniona kwota przypadająca na 1 studenta (choć prostudencka, ilościowa orientacja rozwoju szkolnictwa wyższego także nie jest dobrym pomysłem, podobnie jak finansowanie wg zasady „pieniądze idą za studentem”). Zupełnie inną sprawą jest nieporównywalność PKB różnych krajów, w stosunku do których określa się procentową wielkość odpisu, w tym przypadku na rzecz nauki i szkolnictwa wyższego.

${ }^{7}$ Były to kilkunastostronicowe rozważania, dla których nie ma miejsca w inaczej pomyślanym artykule. Wraz z przedstawionym powyżej zbiorem sugestii z przełomu lat 1991/1992 była to jednak pewna ocena stanu, która mogłaby być podstawą zmian zawartych w ustawie 2.0.

8 Chojnicki (2000); Czyż, Chojnicki (2008a): 146-158; (2008b): 74-95.

${ }^{9}$ Stryjakiewicz et al. (2007); Stachowiak (2017). 
Z nauki i szkolnictwa wyższego uczyniono dziedzinę życia społecznego ograniczająca, przez nieograniczoną praktycznie liczbę studentów, poziom bezrobocia, a dzięki produkcji setek tysięcy dyplomów, za którymi kryje się niski, a co najwyżej przeciętny poziom wiedzy i umiejętności - podniesiono na najwyższy europejski poziom wskaźniki skolaryzacji, skutkiem czego (,pieniądze idące za studentem”) zdeprecjonowano badania naukowe, czyniąc jednocześnie z ich wydumanej oceny (punktacja i pogoń za punktami, a nie rozwiązywanie ważnych problemów naukowych) kryterium finansowego ich dotowania (oceny parametryczne). Na najwyższy poziom podniesiono także wskaźniki liczby doktorów i profesorów (przede wszystkim uczelnianych, choć nie tylko), jaka przypada na 1000 mieszkańców, a proces ten nabiera szczególnego przyspieszenia przed każdą zmianą prawnych regulacji dotyczacych stopni i tytułów naukowych, co prawdopodobnie zapewni najwyższy światowy poziom wymienionego powyżej wskaźnika, deprecjonując i stopnie, i tytuł naukowy profesora. Jednocześnie na nauczycieli akademickich nałożono niespotykany gdzie indziej w Europie wymiar zadań, głównie zajęć dydaktycznych, $\mathrm{w}$ istocie rzeczy wynikający z liczby przyjmowanych studentów, maksymalnie redukując przy tym liczebność grup zajęciowych (obniżka kosztów kształcenia) oraz organizujac dydaktykę w dni wolne od pracy, zazwyczaj bez stosownego wynagrodzenia z tytułu pracy w te dni.

Pod pozorami autonomii i dbałości o jakość kształcenia totalnie zbiurokratyzowano funkcjonowanie szkół wyższych (np. wprowadzenie kosztownego i absorbującego kadry naukowe, nic praktycznie niedającego procesu akredytacji kierunków studiów wyższych poszczególnych uczelni albo wprowadzenie jakoś nie bardzo pasujących do autonomii wyższych uczelni, zwłaszcza w sferze dydaktyki, Krajowych Ram Kwalifikacji). Biurokracja ta zabrała pracownikom naukowym ostatnie w zasadzie godziny, jakie można było przeznaczyć na poważne zajęcie się rozwiązywaniem problemów naukowych. Studentów zaczęto natomiast prowadzić przez proces edukacji za rękę, jak dzieci z pierwszych klas szkoły podstawowej, określając, czego mają się uczyć, co mają wiedzieć i jakie mają być ich kompetencje społeczne. Jednocześnie odpowiedzialnymi za efekty kształcenia uczyniono nauczycieli akademickich, a nie studentów, z których spora ilość, i to z różnych względów, nie powinna nigdy znaleźć się w murach polskich uczelni. Tego typu działania miały zwiększyć międzynarodowy prestiż polskich szkół wyższych, podnieść na wyższy poziom kształcenie i poprawić jego jakość oraz efektywność, a przyniosło wręcz odwrotne od oczekiwanych efekty.

Jednocześnie, tym razem już na najniższym europejskim poziomie, ustalono poziom płac pracowników nauki i szkolnictwa wyższego, zmuszając ich do poszukiwania dodatkowych źródeł dochodów (kosztem pracy naukowej, dydaktycznej, opóźnienia awansu, także kosztem rodziny i zdrowia), o czym już była mowa w niniejszym tekście. Na poziomie, który w niczym nie nawiązuje do znaczenia badań naukowych i wysoko kwalifikowanych kadr dla rozwoju gospodarczego i społecznego kraju, do nałożonych obowiązków, charakteru pracy, drogi awansu, prestiżu zawodowego, potrzeb materialnych nauczycieli akademickich itp. Jest, a właściwie było, do końca 2016 r. jeszcze wiele in- 
nych „pomysłów” na naukę i szkolnictwo wyższe, w toku których opracowania, konkretyzacji i realizacji pomysłodawcy prawdopodobnie nie pomyśleli lub zapomnieli o tym, jaka jest rola nauki i szkolnictwa wyższego w rozwoju gospodarczym i społecznym kraju i czym jest uniwersytet. Wiele osób ze środowisk naukowych z niecierpliwością oczekiwało na sensowna, a zarazem systemowa reformę nauki i szkolnictwa wyższego, choć nadzieje na dobrą zmianę były różnie oceniane. Panowało dość powszechne przekonanie, że potrzebna jest zupełnie nowa ustawa o nauce i szkolnictwie wyższym, czyli napisane na nowo regulacje porządkujace generalne zasady organizacji, struktury i funkcjonowania, a także finansowania nauki i szkolnictwa wyższego (uwzględniające w sferze awansu naukowego i wynagrodzeń zasadę sprawiedliwości społecznej), pozostawiając szczegółowe rozwiązania faktycznie autonomicznym wyższym uczelniom. Byłem optymista co do oczekiwanych zmian, a moją wiarę wspierała teoria samoorganizacji laureata Nagrody Nobla Ilji Prigogine’a, mówiąca, że systemy przechodzące perturbacje wraz z dużym przypływem energii (fluktuacje) uzyskuja ponowy stan równowagi, jednakże na wyższym poziomie oraz w nowej strukturze i nowym funkcjonowaniu. Fluktuacje sa, energia pewnie też jest, a jakie będą efekty, okaże się za kilka lat ${ }^{10}$.

\section{CZYM JEST UNIWERSYTET}

Gdyby zapytać, czym jest uniwersytet dla jego pracowników, można by otrzymać wiele bardzo różnych odpowiedzi. Dla wszystkich uniwersytet jest miejscem pracy, w tym także, jak każde inne takie miejsce, miejscem zarobkowania. Dla wielu jest jednak miejscem realizacji zainteresowań, ambicji, pasji, życiowego celu, doskonalenia się, jest powołaniem, przeznaczeniem, miłościa, miejscem spełnienia oczekiwań, uznania, prestiżu, służenia innym, zapewne dla niektórych także miejscem godziwego spędzania czasu itp. Myślę jednak, że może być również traktowany jako dobro wspólne, a także wspólny interes społeczności akademickiej.

Pierwsze spojrzenie na uniwersytet jako na dobro wspólne wywodzę z tego okresu, kiedy jako prodziekan ds. dydaktycznych czy studenckich jednego z wydziałów miałem okazję poznać osobiście prof. Teresę Rabska, będąca wtedy prorektorem UAM. Był to okres zawieszenia stanu wojennego, w którym środowisko akademickie było przedmiotem szczególnej inwigilacji, a studenci, „specjalnej troski”. W krótkim okresie sprawowania tych funkcji prof. Teresa Rabska wraz z rektorem prof. Franciszkiem Kaczmarkiem i pozostałymi prorektorami została odwołana z pełnionych funkcji, a ja uprzedziłem moje odwołanie z funkcji prodziekana, składając na ręce rektora prof. Kaczmarka dymisję. Przedtem jednak mieliśmy wiele pracy, zwłaszcza kiedy dość częstym wizytom na uczelni oficerów SB towarzyszyły liczne prowokacje w obiektach uniwersyteckich, przede wszystkim w domach studenckich. Pełniąc swoją od-

${ }^{10}$ Prigogine, Stengers (1990). 
powiedzialną funkcję, Profesor Rabska często organizowała spotkania zespołu prodziekanów, na których ustalane były kierunki i sposoby działania w tym trudnym czasie. Wtedy to padały z ust Pani Profesor słowa, abyśmy uczynili wszystko dla obrony tego dobra, jakim jest uniwersytet. Chyba udało się to uczynić, choć nasze działania zostały wkrótce przerwane. Od tego momentu datowała się jednak moja dobra znajomość z śp. Panią Profesor, utrwalana wspólnymi działaniami na rzecz odbudowy samorządów terytorialnych (oboje byliśmy współzałożycielami Wielkopolskiego Ośrodka Kształcenia i Studiów Samorządowych WOKiSS), współpraca w ramach „Ruchu Prawniczego, Ekonomicznego i Socjologicznego" (artykuły, recenzje, polecanie autorów, popularyzacja czasopisma), spotkaniami w środowisku naukowym (Uniwersytet, PTPN) i samorządowym (komitety wyborcze, WOKiSS). Zostałem także zaproszony przez Pania Profesor na obchody 25-lecia odrodzenia polskiej samorządności, aby wraz z najbliższymi jej współpracowniczkami i pod jej przewodnictwem uczestniczyć w sesji jubileuszowej w warszawskim Pałacu Kultury i Nauki.

Kiedy obecnie zastanawiam się nad przyszłością polskiej nauki i szkolnictwa wyższego i buduję różnego rodzaju scenariusze rozwoju sytuacji, wierzę, że nie będzie to tylko kolejna, bezowocna reorganizacja, ale sensowne, przynoszące realne korzyści nauce, szkolnictwu wyższemu, także pracownikom tej sfery życia społecznego, krajowi oraz społeczeństwu - trwałe rozwiąanie systemowe. Mój optymizm w tym zakresie jest jednak raczej umiarkowany. Zapisane w ustawie zmiany odbieram bowiem jako rewolucyjne, a do rewolucji nie mam jakoś zaufania ${ }^{11}$. Bardziej odpowiadają mi zmiany ewolucyjne i nic nie wyklucza ani systemowości, ani głębokości takich zmian. Na ocenę efektów proponowanych kierunków zmian odczekać trzeba będzie kilka, jeśli nie więcej lat. Warto chyba jednak zastanowić się nad tym, co my, jako członkowie społeczności akademickiej, możemy zrobić dla bezbolesnego przejścia ze starego do nowego porządku z korzyścią dla nas wszystkich. Tak się jakoś składa, że w chwilach zadumy nad przyszłością instytucji, w której spędziłem niemal całe moje życie zawodowe, powraca myśl sprzed ponad 35 lat. Myśl, która ukazuje uniwersytet jako dobro wspólne (także wspólny interes), o które zadbać trzeba z należną troską.

\section{CO TO JEST WSPÓLNE DOBRO}

Pojęcie dobra wspólnego jest w pewnym sensie rozwinięciem pojęcia dobra (często zresztą łączonego ze złem). Sokrates za dobro uznawał to, co jest dobre pozytywnie (np. szczęście, wiedza, cnota rozumiana jako virtus), Platon pojmował dobro jako obiektywny byt, natomiast dla Arystotelesa dobro to cel i motyw

11 Mam tu na myśl rewolucje o charakterze politycznym i społecznym, takie jak: wojna chłopska w Niemczech (1524-1526), rewolucja francuska (1789-1795), rewolucja bolszewicka z 1917 r. w Rosji i rewolucja kulturalna w Chinach (1966-1976); jednocześnie zdaję sobie z tego sprawę, że mój pogląd w tym zakresie nie musi być powszechny. Jeden ze znanych poetów przecież pisał: „rewolucja parowóz dziejów, chwała jej maszynistom”. 
dążeń ludzkich ${ }^{12}$. Wielu nowożytnych filozofów uważało, że dobro (i zło) pojmowane może być tylko subiektywnie lub że dobro (i zło) to pojęcie w istocie rzeczy niedefiniowalne, jego rozumienie zaś określa przyjmowany system etyczny ${ }^{13}$. Może warto jeszcze w tym miejscu dodać, że popularne w języku nauk ekonomii „dobro” odnoszone jest do tego wszystkiego, co zaspokaja potrzeby ludzkie, przede wszystkim w sferze materialnej, ale także duchowej (niematerialnej).

Prawdopodobnie wprowadzenie do języka pojęcia dobra wspólnego i jego zdefiniowanie to zasługa św. Tomasza z Akwinu (1225-1274), który wyróżniał dwie kategorie dobra: (1) bonum universi, czyli ład wszechświata (universitas humana), który kieruje człowieka ku Bogu, jako przeznaczeniu i ostatecznemu celowi ${ }^{14}$, oraz (2) bonum commune societatis vel communitatis, czyli dobro społeczne określajace struktury społeczne, a także cele działań i zachowań ludzkich. Jest oczywiście związek między jednym a drugim rozumieniem dobra. Relacje społeczne są bowiem zjawiskami o charakterze masowym, każda społeczność zaś jest formą realizacji ogólnego ładu społecznego, jest uczestnictwem w tym ładzie, i to w takim stopniu, w jakim porządek społeczny jest elementem ogólnego porządku moralnego ${ }^{15}$.

Dobro wspólne powinno zaspokajać potrzeby ludzkie lub przynajmniej zmierzać do ich zaspokojenia. Przede wszystkim prowadzić powinno do zachowania gatunku, rozwoju jednostki i jej osobowości, poznania prawdy, szczęścia, do rozwoju społeczności i jej właściwego wychowania. Ta tomistyczna koncepcja dobra wspólnego stanowi jeden z filarów społecznej nauki Kościoła rzymskokatolickiego. Mimo to dobro wspólne, jak się wydaje, ma dziśs uniwersalne znaczenie, daleko wykraczające poza sferę wiary i religii.

Tworzenie dobra wspólnego w nawiązaniu do poglądów św. Tomasza z Akwinu zakłada przede wszystkim: (1) wspólne zaprowadzanie ładu społecznego jako istoty dobra wspólnego (nad czym czuwać powinna wiarygodna władza), (2) istnienie i funkcjonowanie właśnie wiarygodnej władzy, (3) redystrybutywny charakter dobra (dobro powinno być rozdawane, powszechnie dostępne itp.), (4) godziwość tworzonego dobra (dobro musi być godziwe, tj. dobre w sensie moralnym i odpowiadać wymogom sprawiedliwości społecznej) ${ }^{16}$. Pojęcie dobra wspólnego jest współcześnie nie tylko przedmiotem rozważań filozofów, lecz także przedstawicieli wielu innych dyscyplin naukowych, w tym zwłaszcza prawników ${ }^{17}$. Z dość zróżnicowanego jednak pojmowania dobra wspólnego wyprowadzić można bardziej ogólne jego definiowanie. Nie ulega wątpliwości, że za dobro wspólne jest uznawana jakaś wspólnie wypracowana wartość zbiorowa. Że w ramach danej społeczności jest dobrem jej członków, równych w prawach i powinnościach. Tak pojmowane dobro jest również traktowane jako element porządku demokratycznego i fundament porządku spo-

12 Krapiec (2001): 628-639; Bereś (2008): 127-134.

13 Hussain (2018).

${ }^{14} \mathrm{Na}$ tej koncepcji budowany jest chrześcijański porządek moralny i z czym związane sa takie wartości, jak: dobroć, miłość, sprawiedliwość, miłosierdzie itp.

15 Majka (1982a); (1982b).

16 Majka (1982a); (1982b); Krapiec (2001).

17 Por. Piechowiak (2003): 5-35; Duniewska et al. (2002); Lipowicz (2017): 17-31; Krapiec (2001); Bereś (2008); Hussain (2018). 
łecznego. Często jednak może rodzić się pytanie, czy dobro jednostki nie jest zagrożone ze strony dobra wspólnego lub czy uznanie takiego dobra właśnie za fundament porządku społecznego nie może czasami prowadzić do naruszenia podstawowych praw człowieka. Pytania takie moga być oczywiście formułowane, a odpowiedź na nie jest jednak zazwyczaj negatywna ${ }^{18}$.

Warto może przy tej okazji nadmienić, że w Konstytucji Rzeczypospolitej Polskiej z 2 kwietnia 1992 r. pojęcie dobra wspólnego pojawia się kilka razy. W art. 1 Konstytucji RP znajdujemy zapis, że: „Rzeczpospolita Polska jest dobrem wspólnym wszystkich obywateli"19.

\section{UNIWERSYTET JAKO WSPÓLNE DOBRO}

Odpowiedź na pytanie, czy uniwersytet można potraktować jako dobro wspólne, wymaga odniesienia organizacji, struktury i funkcjonowania tego rodzaju jednostki do rozumienia takiego dobra. Uniwersytet jest bez watpienia dobrem wspólnym jego pracowników oraz studentów, a przynajmniej tak powinien być pojmowany i traktowany. Efektem jego funkcjonowania sa pewne wartości zbiorowe, takie jak wiedza naukowa i wykształcone kadry. Uniwersytet zaspokaja także całą grupę potrzeb społecznych, od zarobkowania począwszy, a na realizacji własnych pasji oraz kształceniu kadr naukowych skończywszy. Wydaje się jednak, że w prowadzonych rozważaniach dotyczących traktowania uniwersytetu jako dobra wspólnego odnieść się należy do tego, co wiąże się z tworzeniem tego dobra oraz określa jego charakter, a na co zwracał uwagę św. Tomasz z Akwinu.

A zatem: (1) działania naukowe, dydaktyczne i organizacyjne powinny być prowadzone w duchu i w ramach ładu społecznego - co więcej, powinny prowadzić do takiego ładu; (2) działania takie powinny być prowadzone pod nadzorem wiarygodnej, legitymizowanej, akceptowanej, najlepiej demokratycznie wybranej władzy; (3) wszyscy pracownicy, a także studenci, powinni korzystać z tworzonego ładu społecznego, który jest istotnym składnikiem dobra wspólnego, (4) uzyskiwane efekty powinny być rzeczywiste, mieć konkretny wymiar, być sprawiedliwie oceniane, nagradzane i moralnie akceptowane.

Jeśli za ład społeczny przyjmuje się pewien porządek, czyli stan funkcjonowania i zachowań jednostek, zapewniajacy istnienie, trwanie i rozwój zbiorowości, to jednocześnie wyznacza się ramy, a następnie kierunki prowadzonych działań. Robić zatem należy wszystko, aby uniwersytet nie tylko trwał, ale aby się rozwijał, i to możliwie najlepiej. Jest to jednak możliwe jedynie w warunkach respektowania określonych wartości, zasad i norm wzajemnej współpracy oraz przy poszukiwaniu dróg do konsensusu i dążeniu do jego uzyskania. Zupełnie inna, nie mniej ważna, sprawą jest istnienie odpowiednich materialnych warunków funkcjonowania. Sprawy te są jednak pomijane w niniejszym opracowaniu.

18 Por. Piechowiak (2003); Lipowicz (2017).

$19 \mathrm{Z}$ postanowień Konstytucji RP jednoznacznie wynika, że interpretację dobra wspólnego przyjęto w nawiązaniu do nauki społecznej Kościoła katolickiego. 
Tworzenie ładu (porzadku) społecznego

Za najważniejsze czynniki tworzenia ładu społecznego uważa się prawo, etykę, moralność, sprawiedliwość, światopogląd, a także tradycję. To te czynniki w zasadniczy sposób określają zasady funkcjonowania zbiorowości, sa źródłem norm i wartości, a tym samym tworzą fundamenty porządku społecznego i regulują stosunki między ludźmi, konkretnie: członkami danej społeczności, w tym przypadku uniwersyteckiej (akademickiej). Warto przytoczyć w tym miejscu często wyrażany pogląd, że zdrowe funkcjonowanie danej społeczności jest praktycznie niemożliwe bez uzyskania porządku społecznego, jak również i ten, że ład społeczny jest podstawowym czynnikiem kształtującym jakość życia i pracy. Tworzenie ładu społecznego wymaga współpracy, dobrej woli i konsensusu wszystkich członków konkretnej społeczności, a to nie jest ani łatwe, ani proste, zwłaszcza w przypadku społeczności akademickiej. Cały problem tkwi w wyjątkowym zróżnicowaniu osobowości poszczególnych członków tej społeczności, u ich podstaw działania zaś znajdują się określone racje. Racja to nic innego jak subiektywnie przyjmowana słuszność prezentowych poglądów, punktu widzenia, stanowiska, przekonań, postępowania itp. To właśnie różne racje są przyczyną nie tylko dyskusji i debat, lecz także sporów, konfliktów, nieporozumień, a nawet wrogości. Oczywiście należy dyskutować, także spierać się, jednakże na płaszczyźnie przedstawiania własnych racji. Niestety, do konsensusu (także do zgody) prowadzić moga jedynie racje oparte na prawdzie, a z prawdą w warunkach społecznych, w jakich żyjemy, jest coraz gorzej.

Arystoteles zdefiniował prawdę w następującym sformułowaniu: „Powiedzieć o tym, co jest, że jest, a o tym, czego nie ma, że go nie ma, jest prawdą”. Natomiast św. Tomasz z Akwinu wyróżniał trzy ujęcia prawdy: (1) metafizyczne: verum est id, quod est, czyli prawda jest to, co jest (prawdziwe jest to, co istnieje); (2) teoriopoznawcze: verum est adaequatio intellectus et rei, a zatem prawda zachodzi wówczas, jeżeli to, co jest w naszym intelekcie, jest zgodne z rzeczywistościa, oraz (3) logiczne: verum est manifestativum et declarativum esse, czyli wszystko, co wskazuje na prawdę, ukazuje ja, prowadzi do niej ${ }^{20}$.

Prawda jest właściwością sądów polegającą na ich zgodności z faktycznym stanem rzeczy, których dotycza. Celem nauki jest poszukiwanie prawdy, jednakże prawda powinna być także fundamentem prezentowanych racji w dyskusjach nad rozwiązaniem występujących problemów. Dyskutujmy, spierajmy się, lecz poszukujmy konsensusu w ramach racji opartych na prawdzie. Twórzmy w naszym wspólnym działaniu zgodna, współpracującą wspólnotę. W filozofii chrześcijańskiej przyjmuje się, że fundamentem prawdy jest miłość, że nie ma prawdy bez miłości, oczywiście miłości bliźniego.

Funkcjonowanie władzy społecznej

Funkcjonowanie władz uniwersytetu określają: ustawa (powszechne prawo nauki i szkolnictwa wyższego) oraz statut jednostki (prawo lokalne). $\mathrm{Na}$ razie władze uczelni są legitymizowane, ponieważ pochodzą z wyboru. $\mathrm{O}$ ich

${ }^{20}$ Spotkać można często nie tyle definicje, ile specyficzne klasyfikacje prawdy. W filozofii po góralsku ks. Józef Tischner wyróżnia trzy kategorie prawdy. Sa to: „świento prowda, tys prowda i gówno prowda". Oczywiście prawdą jest tylko ta pierwsza kategoria; por. Tischner (2018). 
funkcjonowaniu (relacjach, jakie tworza) decyduje wiele czynników różnej natury. Ujmowany w kontekście niniejszych rozważań problem tkwi w tym, aby władze te podjęły się roli kierowniczej w procesie tworzenia dobra wspólnego, w tym i ładu społecznego, i dbały o to, aby prawda była podstawą rozwiazywania sporów, a podejmowane decyzje były konsensusem ścierania się różnych racji.

Redystrybutywny charakter dobra

Na dobro, jakie wspólnie w uniwersytecie, ale i każdym środowisku naukowym tworzymy, składają się, mówiąc ogólnie, działalność: naukowa, dydaktyczna i organizacyjna. Dobro wspólne pomagają zaś tworzyć przyjmowane: prawo, zasady, reguły, kryteria oceny, normy postępowania i zapewne inne czynniki. W ramach dobra wspólnego mieszczą się także wzajemny szacunek, współpraca, uznanie, także zdrowa i szlachetna konkurencja. Z wspólnie tworzonego dobra, jakim jest uniwersytet, powinni korzystać w możliwie maksymalnym stopniu i bez żadnych ograniczeń, stosownie do miejsca w społeczności akademickiej, zarówno pracownicy, jak i studenci. Pracownicy w nawiąaniu do posiadanych kompetencji (stanowisko, funkcja) i uprawnień (stopnie i tytuły), natomiast studenci - zgodnie z ich miejscem i rolą w społeczności uniwersyteckiej oraz regulaminowymi regulacjami. Tworzone dobro wspólne obejmuje bowiem swoim zakresem to wszystko, co mieści się w pracy naukowej, dydaktycznej i organizacyjnej, a co wielokrotnie już podkreślano. Innymi słowy, wszyscy powinni być obdarzani wspólnie tworzonym dobrem.

Godziwość dobra (dobroć, sprawiedliwy charakter oraz moralna akceptowalność)

Wszystko, co robimy, powinniśmy się starać robić jak najlepiej, odpowiedzialnie, uczciwie, zgodnie z posiadaną wiedzą oraz opartymi na prawdzie racjami. Tworząc dobro we własnym środowisku, tworzymy także dobro dla innych. Pomocna w tym działaniu jest etyka, zarówno uniwersalna, jak i etyka pracy naukowej i dydaktycznej. Dotyczy to zarówno wynikających z naszych obowiązków działań, jak i z relacji w lokalnej społeczności, jaką tworzymy. Zatem wszystko, co robimy, powinno być dobre, szlachetne, godziwe, co oznacza moralną akceptowalność naszych działań, a co może zawsze jest oczywiste, ale nie zawsze tak jest.

Choć dobro uniwersytetu jako szeroko pojmowanego miejsca pracy sprowadzone zostało do troski o ład społeczny oraz do tworzenia ładu społecznego w ramach prowadzonej działalności, to takie bardzo ogólne ujęcie pozostawia zawsze wiele miejsca na szczegółowe sformułowania w nawiązaniu do obowiązujących uniwersytet regulacji prawnych. Tego rodzaju traktowanie uniwersytetu jest szczególnie ważne, kiedy w życie wprowadzać się będzie zupełnie nowe, często rewolucyjne rozwiązania ustawowe, kiedy kształtowana będzie nowa organizacja uniwersytetu, kiedy pracę naukową i dydaktyczna, podobnie zresztą jak strukturę uniwersytetu, powiązać trzeba będzie z nowo zadekretowanymi dyscyplinami oraz dziedzinami nauki, kiedy inaczej ukształtują się zespoły współpracujących z sobą osób. Wszystkie te zmiany mają prowadzić 
do dostosowania organizacji polskiej nauki i szkolnictwa wyższego do standardów międzynarodowych. Taki jest zamiar ustawodawcy. Rzeczywistość zweryfikuje te zamiary.

\section{UNIWERSYTET JAKO WSPÓLNY INTERES}

$\mathrm{Na}$ uniwersytet można także patrzeć jako na wspólny interes, co w pewnym sensie nawiązuje do uprzednio opisanego dobra wspólnego. Istotę wspólnego interesu najlepiej wyprowadzić z czegoś, co nazwać można ukierunkowaniem podejmowanych względnie prowadzonych działań.

W każdym podejmowanym przez pojedynczą osobę lub grupę ludzi działaniu zawsze chodzić będzie o: (1) dobro jednostki (danej, konkretnej), (2) dobro małej grupy, do której należy jednostka (np. rodziny bliższej lub dalszej, grupy koleżeńskiej, grupy pracowniczej), (3) dobro większej zbiorowości, do której należy jednostka (społeczność lokalna, społeczność regionalna, społeczeństwo, naród), (4) dobro innych małych grup, do których nie należy jednostka, zewnętrznych względem niej, (5) dobro większych zbiorowości, do których nie należy jednostka, (6) dobro wszystkich, dobro powszechne (wszystkich ludzi).

W powyższej klasyfikacji kategorię interesów reprezentują dobro jednostki, dobro małych grup, do których należy jednostka, oraz dobro większej zbiorowości, do których należy jednostka. Dobro innych grup, w skład których nie wchodzi dana jednostka, zarówno małych, większych, jak i dobro wszystkich, a także wymienione powyżej dobro większej zbiorowości, w skład której wchodzi jednostka, reprezentuje kategorię tzw. wartości ${ }^{11}$.

Funkcjonując jako uniwersytet, ale także jako szkoła, wydział, instytut, katedra czy też inna jednostka organizacyjna, zobowiązani jesteśmy do troski o dobro każdego z nas, o dobro jednostki organizacyjnej, w której pracujemy, oraz o dobro uniwersytetu, jako całości, która obejmuje zarówno pracowników, jak i studentów ${ }^{22}$. Innymi słowy, troska ta leży w naszym interesie, mówiąc inaczej, jest naszym interesem. Naszym, tj. członków społeczności uniwersyteckiej.

Interesy i wartości traktowane łącznie określają z kolei świadomość społeczna, którą powinniśmy kształtować i rozwijać, od poziomu jej rozwoju zależą bowiem uzyskiwane efekty. Pisząc konkretnie, od poziomu rozwoju świadomości zależeć będzie pojmowanie dobra, wartości i interesów oraz ich uznawanie, docenianie i uwzględnianie $\mathrm{w}$ podejmowanych i prowadzonych działaniach. Świadomość społeczna to zaś nic innego, jak: (1) istnienie zbioru wspólnych dla danej zbiorowości czy grupy społecznej przekonań, (2) pojmowanie i uznanie tych przekonań za wspólne i ważne dla danej zbiorowości (grupy społecznej), (3) uznanie tych przekonań za przesłanki działań indywidualnych na większą skalę, zwłaszcza zaś wspólnych działań zbiorowych ${ }^{23}$. Jest zapewne

${ }^{21}$ Por. Ziółkowski (2000).

${ }^{22}$ Oczywiście w prowadzonych działaniach nie można zapominać także o dobru innych grup, ale to jest sprawa drugorzędna w niniejszych rozważaniach.

${ }^{23}$ Ziółkowski (2000). 
wiele wspólnych przekonań kształtujących świadomość społeczną społeczności uniwersyteckiej, wymienić można m.in.: rozumienie roli, jaka pełnić ma uniwersytet w społeczeństwie i państwie, przekonanie o wolności i uczciwości prowadzonych badań naukowych oraz wysokim ich poziomie, a także o obowiązku kształcenia wysoko kwalifikowanych kadr. Wspólnym przekonaniem powinno być także traktowanie uniwersytetu jako dobra wspólnego, czego dotyczy niniejszy tekst, a z czym wiąże się troska o jego rozwój, efektywne funkcjonowanie oraz duże znaczenie w środowisku naukowym kraju, Europy i świata. Tego rodzaju, jak wymieniono powyżej, ale także i inne przekonania muszą być uznawane za wspólne i ważne dla całej społeczności uniwersyteckiej. Powinny także składać się na przesłanki indywidualnych i wspólnych działań dla dobra uniwersytetu, nauki oraz edukacji młodego pokolenia. Innymi słowy, działania te powinny realizować podstawowy interes uniwersytetu, jakim jest tworzenie wiedzy naukowej oraz kształcenie elity intelektualnej.

\section{ZAKOŃCZENIE}

Interpretacja ogólnego modelu uniwersytetu (szkoły, wydziału, instytutu, katedry itp.) w kategoriach dobra wspólnego (także wspólnego interesu oraz wartości) jest jedynie jednym z możliwych do rozważania ujęć. Co więcej, opiera się na przyjęciu pewnych ogólnych złożeń, które w obecnych czasach nie sa zbyt popularne. Takie pojęcia, jak: wartości, autorytety, racje, prawda, dobro, etyka, moralność - bądź są odrzucane, funkcjonują z przymiotnikami, bądź też sa zastępowane nowymi (prawdę zastępuje postprawda, etykę - relatywizm moralny, racje - poprawność polityczna, wartości uniwersalne - wartości europejskie itp.). Prezentowane w niniejszym tekście stanowisko jest być może archaiczne, tradycyjne, niedzisiejsze, wydumane, a przez to nierealne. Wynika jednak z przeświadczenia, że są pewne wartości uniwersalne i tych się na razie nie zmieni. Wśród tych wartości sa oczywiście dobro wspólne i silnie z nim powiązane: prawda, sprawiedliwość, odpowiedzialność, honor, uczciwość, zaangażowanie, szacunek, tolerancja i wiele innych przymiotów. Można to wszystko oczywiście odrzucić lub potraktować selektywnie, ale jakie będą tego efekty? $\mathrm{Na}$ to pytanie nie ma dziśs odpowiedzi. Dziś, to jest w czasach, kiedy hasło „ruszymy z posad bryłę świata”, jest znowu aktualne, choć w innym, ideologicznym kontekście. Celem nauki było i jest nadal poszukiwanie prawdy. Jak tę prawdę można poszukiwać i znaleźć, kiedy się ją relatywizuje lub odrzuca?

Polska nauka i szkolnictwo wyższe stają dziś w punkcie zwrotnym, który wyznacza Konstytucja dla nauki 2.0. Ustawa ta wpisuje się w niemal powszechne oczekiwanie na reformę systemowa, która stopniowo staje się faktem. Rewolucyjny charakter proponowanych zmian może jednak budzić i budzi wiele watpliwości. Może i dobrze, że zapisane w ustawie zmiany sa stopniowo wprowadzane w życie. Trzeba się jednak do nich, także stopniowo, dostosować, czy nam się to podoba czy też nie. Dura lex sed lex, jak to zapisano w prawie rzymskim. Może więc warto, tworząc nową strukturę uniwersytetu, 
wpisując się w nowe dziedziny i nowe dyscypliny naukowe, mieć na uwadze także i to, że jako całość uniwersytet jest naszym dobrem wspólnym. Nowe regulacje prawne są wyzwaniem dla nas wszystkich, jednocześnie prawdopodobnie sa i szansą na dalszy, pomyślny rozwój tej jednostki, w której wszyscy pracujemy. Uznając, że uniwersytet jest naszym dobrem wspólnym, wspólnie pracujmy dla jego dobra. Może chwila refleksji nad tym tekstem będzie nam pomocna w naszych działaniach.

Jerzy J. Parysek

Uniwersytet im. Adama Mickiewicza w Poznaniu

parys@amu.edu.pl

https://orcid.org/0000-0003-0044-6582

Bereś, B. (2008). Dobro wspólne jako cel i kryterium życia społecznego. Aspekt pedagogiczny. Roczniki Nauk Społecznych 36(2): 127-134.

Bertalanffy, L. von (1950). An outline of general system theory. British Journal of the Philosophy of Science 1(2): 134-165.

Bertalanffy, L. von (1968). General System Theory: Foundations, Development, Application. New York: G. Braziller.

Chojnicki, Z. (2000). Filozofia nauki. Poznań: Bogucki Wydawnictwo Naukowe.

Czyż, T., Chojnicki, Z. (2008a). Gospodarka oparta na wiedzy jako czynnik rozwoju regionalnego. Biuletyn KPZK PAN 237: 146-158.

Czyż, T., Chojnicki, Z. (2008b). Gospodarka oparta na wiedzy w regionach metropolitalnych i aglomeracjach miejskich w Polsce. Studia KPZK PAN 120: 74-95.

Duniewska, Z., Jaworska-Dębska, B., Michalska-Badziak, R., Olejniczak-Szałowska, E. (2002). Prawo administracyjne pojęcia, instytucje, zasady w teorii i orzecznictwie. Warszawa: Wydawnictwo Difin.

Hussain, W. (2018). The common good, [w:] Stanford Encyclopedia of Philosophy. Stanford. Center for the Study of Language and Information [Online: <https://plato.stanford.edu/entries/ common-good>].

Krapiec, M.A. (2001). Dobro wspólne, [w:] Powszechna encyklopedia filozofii. Tom 3. Lublin: Wydawnictwo Polskiego Towarzystwa Tomasza z Akwinu: 628-639.

Lipowicz, I. (2017). Dobro wspólne. Ruch Prawniczy, Ekonomiczny i Socjologiczny 79(3): 17-31.

Majka, J. (1982a). Etyka życia gospodarczego. Wrocław: Wydawnictwo Wrocławskiej Księgarni Archidiecezjalnej.

Majka, J. (1982b). Filozofia społeczna. Wrocław: Wydawnictwo Wrocławskiej Księgarni Archidiecezjalnej.

Piechowiak, M. (2003). Filozoficzne podstawy rozumienia dobra wspólnego. Kwartalnik Filozoficzny 21(2): 5-35.

Prigogine, I., Stengers, I. (1990). Z chaosu ku porządkowi. Biblioteka Myśli Współczesnej. Warszawa: PIW.

Stachowiak, K. (2017). Gospodarka kreatywna i mechanizmy jej funkcjonowania. Perspektywa geograficzno-ekonomiczna. Poznań: Wydawnictwo Naukowe Uniwersytetu im. A. Mickiewicza w Poznaniu.

Stryjakiewicz, T., Kaczmarek, T., Męczyński, M., Parysek, J., Stachowiak, K. (2007). Poznań Faces the Future. Pathways to Creative and Knowledge-Based Regions. Amsterdam: University of Amsterdam.

Tischner, J. (2018). Historia filozofii po góralsku. Kraków: Znak.

Ziółkowski, M. (2000). Przemiany interesów i wartości społeczeństwa polskiego. Teorie, tendencje, interpretacje. Poznań: Wydawnictwo Humaniora. 
THE UNIVERSITY AS A COMMON GOOD AND A COMMON INTEREST

\section{Sum mary}

New legal regulations concerning the organization, structure and functioning of science and higher education, called the Constitution for Science 2.0 (Act of 20 July 2018 on Higher Education and Science), mean a revolutionary transformation of Polish scientific and educational institutions. The proposed changes, even though they were widely expected in academic circles awaiting a systemic reform, raise many objections and hopes at the same time. However, the changes are being gradually implemented and one must adapt to them (dura lex sed lex). Therefore, while adapting our activity to the new conditions of the functioning of the university, when co-creating its new structure, registering one's own scientific and didactic activity as a new branch and discipline of science, and taking a particular position regarding the ongoing changes, it may be worth paying attention to the fact that the university as a whole is our common good and its effective functioning is a common interest of the academic community. The article aims to apply the ideas of the common good and the common interest to understanding the university and the functioning of its community. This is important when new legal regulations, being a new challenge, are probably also an opportunity for the further, successful development of the institution we all work in. These kinds of deliberations are preceded by a reconstruction of the state of Polish science and higher education in the years before the changes were implemented, together with the changes that were suggested over the years. The reflections contained in this text may be helpful in our thinking and our activity. This paper presents the subjective views and opinions of the author. It is dedicated to the late Professor Teresa Rabska, the Editor-in-Chief of the Ruch Prawniczy, Ekonomiczy $i$ Socjologiczny (Journal of Law, Economics and Sociology) for many years, who, as a Vice-Rector of Adam Mickiewicz University in Poznań, in the difficult times of martial law encouraged her co-workers to defend this common good, which is the university, and to care about its prosperity.

Keywords: university; common good; common interest 
